\title{
Kesalahan Penggunaan Huruf Kanji Dalam Buku Intermediate Kanji Book Vol. 1 Pada Mahasiswa Semester 3 Angkatan 2016 Program Studi Sastra Jepang FIB UNUD
}

\author{
I Nyoman Rauh Artana'), I Made Budiana ${ }^{2)}$ \\ Universitas Udayana \\ rauhartana@gmail.com ${ }^{1)}$,budi.hybrid@gmail.com ${ }^{2)}$
}

\begin{abstract}
This research was conducted to find out the forms of errors made by the 3rd semester 2016 students of Japanese Literature Study Program, Faculty of Arts, Udayana University in understanding and using the words with the kanji letters found in the Intermediate Kanji Book Vol. 1. The problems discussed in this study, namely 1) what is the fault of students in understanding and using words with starch in the Intermediate Kanji Book Vol. 1; 2) how to overcome errors in understanding and using words with kanji in the Intermediate Kanji Book Vol. 1. The purpose of this study is to find out the forms of errors made by students in understanding and using words with kanji in the Intermediate Kanji Book Vol. And find a way to overcome these errors. This research is a descriptive qualitative research with documentation method and test method which is continued with note taking technique. The documentation method in this study is a collection of questions that have been filled in with answers by informants. While the test method is an instrument of data collection through a series of questions / exercises distributed to students. The population in this study were all students of the 3rd Semester of the 2016 Class of Japanese Literature Study Program, Faculty of Cultural Sciences Universitas Udayana. The determination of the population is based on the consideration that the 3rd semester 2016 students have been taught material contained in the Intermediate Kanji Book Vol. 1. Through this research, the forms of student errors mentioned above will be able to be broken down and find solutions to overcome them. And the results of this study can be used as teaching materials for lecturers and study materials for students majoring in Japanese literature.
\end{abstract}

Keywords: error, usage, kanji, Japanese

\section{Pendahuluan}

Bahasa Jepang memiliki karakteristik yang unik, seperti pada huruf yang dipakainya, kosakata, sistem pengucapan, gramatika, dan ragam bahasanya. Dilihat dari huruf yang dipakai untuk menuliskan bahasa Jepang, kita akan tahu bahwa bahasa Jepang memiliki sistem penulisan yang sangat kompleks, karena menggunakan empat perangkat huruf, yakni Kanji, Kana yang terdiri atas Hiragana dan Katakana, serta Romaji ( Iwabuchi, 1989 : 180 ). Dari keempat jenis-jenis huruf diatas, huruf yang 
paling sulit untuk dipelajari bagi pembelajar bahasa Jepang adalah kanji. Walaupun ada huruf Hiragana dan katakana, kanji merupakan salah satu huruf yang memegang peranan penting untuk berkomunikasi dengan orang Jepang lewat tulisan.

Kanji melambangkan suatu arti tertentu. Satu kanji dapat dibaca secara dua bacaan, yaitu On'yomi (音読み) adaptasi dari cara baca China, dan Kun'yomi (訓読み) cara baca asli Jepang. Satu kanji bisa memiliki beberapa bacaan On'yomi (音読み) dan Kun'yomi (訓読み).Kanji sangat penting untuk dipelajari, apalagi untuk para mahasiswa-mahasiswa yang mempelajari bahasa Jepang. Selain untuk berkomunikasi dengan orang Jepang lewat tulisan, mempelajari kanji juga nantinya dapat membantu mereka dalam menghadapi Nouryoku Shiken (ujian tes kemampuan bahasa Jepang). (Chusna, $2014: 2$ ).

Dalam pembelajaran bahasa Jepang di Program Studi Sastra Jepang Fakultas Ilmu Budaya Universitas Udayana seringkali ditemukan kesalahan yang dilakukan oleh pembelajar bahasa Jepang dalam memahami penggunaan huruf kanji yang terdapat pada buku pelajaran Intermediate Kanji Book Vol. 1. Mahasiswa seringkali melakukan kesalahan ketika mengerjakan latihan soal-soal. Dan kesalahan yang paling sering ditemukan pada mahasiswa adalah menggunakan huruf kanji yang bersinonim, baik dari segi makna, ucapan, jenis dan pengelompokkan kata.

Berkaitan dengan kesalahan berbahasa (Setyawati, 2010: 15-16) menyatakan bahwa kesalahan bahasa pada dasarnya disebabkan pada diri orang yang menggunakan bahasa yang bersangkutan bukan pada bahasa yang digunakannya. Ada tiga kemungkinan penyebab seseorang dapat salah dalam berbahasa, antara lain: 1) terpengaruh bahasa yang lebih dahulu dikuasainya; 2) kekurangpahaman pemakai bahasa terhadap bahasa yang dipakainya, dan 3) pengajaran bahasa yang kurang tepat atau sempurna.

Sejalan dengan pernyataan Setyawati di atas, kesalahan mahasaiswa dalam memahami dan menggunakan huruf kanji pada buku Intermediate Kanji Book Vol. 1 mungkin disebabkan karena tiga kesalahan seperti yang dikatakan Setyawati. Untuk mengetahui hal tersebut dirasa perlu untuk dilakukan penelitian ini.

Masalah yang dibahas dalam penelitian ini adalah: pertama "Bagaimanakah kesalahan mahasiswa dalam memahami dan menggunakan kata-kata dengan huruf kanji yang terdapat pada buku pelajaran Intermediate Kanji Book Vol. 1?"; kedua "Bagaimanakah cara untuk mengatasi kesalahan dalam memahami dan menggunakan kata-kata dengan huruf kanji yang terdapat pada buku pelajaran Intermediate Kanji Book Vol. 1?"

\section{Metode Penelitian}

Metode penelitian yang digunakan dalam penelitian ini adalah penelitian deskriptif kualitatif. Metode penelitian kualitatif sering disebut metode penelitian natutalistik karena penelitiannya dilakukan pada kondisi yang alamiah (natural setting). Penelitian dilakukan pada obyek yang alamiah. Obyek yang alamiah adalah obyek yang berkembang apa adanya, tidak dimanipulasi oleh peneliti dan kehadiran peneliti tidak begitu mempengaruhi dinamika pada obyek tersebut. (Sugiyono, 2014:15). Sejalan dengan metode yang digunkan dalam penelitian ini, yaitu penelitian 
deskriptif kualitatif maka masalah yang dibahas berupa jawaban dari soal-soal yang terdapat dalam buku Intermediate Kanji Book Vol. 1. Populasi dalam penelitian ini adalah semua mahasiswa Semester 3 Angkatan 2016 Program Studi Sastra Jepang Fakultas Ilmu Budaya Universitasa Udayana. Pada penelitian ini digunakan teknik penelitian total sampling, yakni semua mahasiswa yang ada dalam populasi di atas dijadikan populasi penelitian sekaligus juga merupakan sampel penelitian, yaitu semua mahasiswa semester 3 angkatan 2016 Program Studi Sastra Jepang Fakultas Ilmu Budaya Universitasa Udayana. Penentuan populasi tersebut didasarkan atas pertimbangan bahwa mahasiswa semester 3 angkatan 2016 pada semester sebelumnya telah diajarkan materi yang terdapat dalam buku Intermediate Kanji Book Vol. 1.

Pengumpulan data dalam penelitian ini menggunakan metode dokumentasi dan metode tes. Metode dokumentasi dalam penelitian ini berupa kumpulan soal-soal yang telah diisi jawaban oleh informan, yaitu mahasiswa semester 3 angkatan 2016 program studi sastra Jepang fakultas ilmu budaya universitas Udayana. Sedangkan metode tes adalah instrumen pengumpulan data serangkaian pertanyaan/latihan yang digunakan untuk mengukur keterampilan pengetahuan, intelegensi, kemampuan atau bakat yang dimiliki individu /kelompok (Wilian, 2009). Teknik catat juga dilakukan sebagai teknik lanjutan setelah peneliti membaca sumber data, peneliti dalam upaya mendapatkan data dilakukan dengan mencatat kesalahan mahasiswa dalam menjawab soal-soal latihan yang terdapat dalam buku Intermediate Kanji Book Vol. 1.

Peneliti menggunakan teknik lanjutan dalam metode padan berupa teknik pilah unsur penentu. Metode ini digunakan untuk mengetahui faktor penyebab terjadinya kesalahan mahasiswa dalam dalam menggunakan kata-kata dengan huruf kanji yang terdapat pada buku Intermediate Kanji Book Vol. 1. Sehubungan dengan hal tersebut, menurut Ellis Tarigan \& Tarigan (dalam Utami, 2015:37--38) menyatakan bahwa terdapat lima langkah kerja analisis bahasa. Lima langkah kerja analisis bahasa digunakan pada penelitian ini. Langkah analisis bahasa yang digunakan untuk menganalisis data adalah sebagai berikut:

1) Mengumpulkan sampel kesalahan: Sampel jawaban soal-soal yang ada di buku Intermediate Kanji Book Vol. 1 dipilah dan dikumpulkan; 2) Mengidentifikasi kekesalahan: Memilah-milah soal-soal tersebut sehingga dimungkinkan untuk diketahui bentuk kesalahan jawaban mahasiswa; 3) Menjelaskan kesalahan: Dalam hal ini menggambarkan letak kesalahan, penyebab kesalahan dan memberikan contoh yang benar dari hasil tes yang dilakukan oleh mahasiswa; 4) Mengklasifikasikan kesalahan: Mengklasifikasikan kesalahan mahasiswa dengan melihat hasil jawan yang ada di lembar jawaban; 5) Mengevaluasi kesalahan: Mengevaluasi kesalahan yang dilakukan oleh mahasiswa dalam menjawab soal-soal latihan yang ada di buku buku Intermediate Kanji Book Vol. 1.

Dapat dijelaskan bahwa alir penelitian ini diadaptasi dari langkah-langkah kerja yang dikemukakan Ellis Tarigan \& Tarigan (dalam Utami, 2015:37--38) menyatakan bahwa terdapat lima langkah kerja analisis bahasa. Lima langkah kerja analisis bahasa digunakan pada penelitian ini. Langkah analisis bahasa yang digunakan untuk menganalisis data adalah sebagai berikut: 1) Mengumpulkan sampel kesalahan

Sampel jawan soal-soal yang ada di buku Intermediate Kanji Book Vol. 1 dipilah dan dikumpulkan; 2) Mengidentifikasi kekesalahan Memilah-milah soal-soal 
tersebut sehingga dimungkinkan untuk diketahui bentuk kesalahan jawaban mahasiswa; 3) Menjelaskan kesalahan Dalam hal ini menggambarkan letak kesalahan, penyebab kesalahan dan memberikan contoh yang benar dari hasil tes yang dilakukan oleh mahasiswa; 4) Mengklasifikasikan kesalahan Mengklasifikasikan kesalahan mahasiswa dengan melihat hasil jawan yang ada di lembar jawaban; 5) Mengevaluasi kesalahan Mengevaluasi kesalahan yang dilakukan oleh mahasiswa dalam menjawab soal-soal latihan yang ada di buku buku Intermediate Kanji Book Vol. 1. Setelah mengevaluasi kesalahan selanjutnya dilakukan analisa data. Tahapan berikutnya yaitu menyimpulkan hasil analisis data.

\section{Pembahasan}

Sesuai dengan rumusan masalah yang pertama, yang terdapat pada bab 1 sebelumnya, maka pada bab ini diuraikan 'kesalahan mahasiswa dalam memahami dan menggunakan kata-kata dengan huruf kanji yang terdapat pada buku pelajaran Intermediate Kanji Book Vol. 1'. Adapun kesalahan-kaesalahan tersebut adalah:

3.1. Kesalahan dalam memahami dan menggunakan 漢字の仲間 'kanji no nakama', yaitu kanji yang dikelompokkan berdasarkan 部首 'bushur/radicals'

a. kesalahan mahasiswa dalam memahami 形のグループ＇katachi no guru-pu' (pengelompokkan huruf kanji berdasarkan karakter bentuk), yaitu kesalahan dalam menentukan huruf kanji berdasarkan: (1) Hen (偏) $\square$, yaitu bushu yang berada pada bagian kiri huruf kanji; (2) Tsukuri (旁) $\square$, yaitu bushu yang berada pada bagian kanan huruf kanji; (3) Kanmuri (冠) 曰, yaitu bushu yang berada pada bagian atas huruf kanji; (4) Ashi (脚) 日, yaitu bushu yang berada pada bagian bawah huruf kanji; (5) Tare

(垂) Ш, yaitu bushu yang membentuk siku-siku dari bagian atas ke bagian kiri; (6) Nyō (繞) 【, yaitu bushu yang membentuk siku-siku dari bagian kiri ke bagian bawah; (7) Kamae (構) 回回回四, yaitu bushu yang tampak seolah-olah mengelilingi bagian huruf kanji lainnya.

b. 音のグループ 'oto no guru-pu' ( pengelompokkan huruf kanji berdasarkan karakter bunyi ) atau disebut dengan 形声文字 'keisei moji' Keisei (形声 'karakter piktofonetik') Keisei adalah metode pembentukan huruf kanji dengan menggabungkan dua huruf kanji yang terbentuk dari metode shōkei, metode shiji, dan metode kai'i. Salah satu bagian dari huruf kanji memiliki fungsi untuk menunjukkan makna ( $g i f u$ / 義符 atau iful 意符) yang disebut dengan radikal dan bagian lainnya memiliki fungsi untuk menunjukkan bunyi pelafalan (seifu/声符 atau onpu/音符) yang disebut dengan radikal fonetik.

c. 意味のグループ ‘imi no guru-pu' ( pengelompokkan huruf kanji berdasarkan arti/makna ) huruf kanji dapat dikelompokkan berdasarkan: 1) 人間関係の漢字 'ningen kankei no kanji' kanji yang dikelompokkan berdasarakan hubungan keluarga, yaitu: 父 、母、兄、姉、弟、妹; 2) 位置を表す漢字 'ichi wo arawasu kanji' kanji yang dikelompokkan 
berdasarkan posisi/ menyatakan makna tentang posisi, yaitu: 左、右、前、後了、上、下、 中；3）方角 'hougaku’ kanji yang dikelompokkan berdasarkan arah, yaitu: 東、西、南 、北；4) 季節 'kisetsu' kanji yang dikelompokkan berdasarkan musim, yaitu: 春、夏、秋 、冬 ; 4) 色 'iro' kanji yang dikelompokkan berdasarkan nama warna, yaitu: 赤、青、黒 、白、茶；5) 行政区分 'gyousei kubun) kanji yang dikelompokkan berdasrkan pembagian daerah wilayah, yaitu: 都、道、府、県、市、区、町、村; 6) 専門分野 'senmon bunya' kanji yang dikelompokkan berdasarkan bidang studi akademis, dan lain sebagainya.

d. 用法のグループ 'youhou no guru-pu' (pengelompokkan huruf kanji berdasarkan penggunaannya ) berdasarkan penggunaannya huruf kanji dapat dikelompokkan berdasarkan kelas kata, yaitu: 1) イ形容詞：高い、安い、多い、少ない、長い、短い、dll; 2) ナ 形容詞：元気な、有名な、便利な、適当な、dll, 3) 動詞：話す、聞く、読む、書く、食べる、飲む、 dll, 4）する動詞：練習する、勉強する、研究する、質問する、dll, 5)〈場所〉の接尾辞：～所、～場、～地 、～園、 館、dll, 6)〈仕事〉の接尾辞：～家、〜手、〜者、〜員、〜人、dll, 7)〈お金〉の接尾辞：

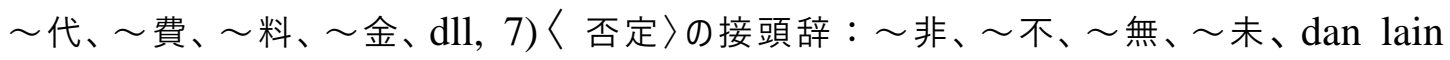
sebagainya.

Radikal (bushu/部首) merupakan bagian-bagian yang ada pada sebuah huruf kanji yang menjadi dasar untuk mengklasifikasi huruf kanji. Terdapat tujuh macam bushu sesuai dengan letaknya pada huruf kanji (Sudjianto, 2004:59), yaitu:

(1) Hen (偏) Ш, yaitu bushu yang berada pada bagian kiri huruf kanji.

(2) Tsukuri (旁) $\square$, yaitu bushu yang berada pada bagian kanan huruf kanji.

(3) Kanmuri (冠) 日, yaitu bushu yang berada pada bagian atas huruf kanji

(4) Ashi (脚) $\boxminus$, yaitu bushu yang berada pada bagian bawah huruf kanji

(5) Tare (垂) $\square$, yaitu bushu yang membentuk siku-siku dari bagian atas ke bagian kiri.

(6) $\quad N y \bar{o}$ (繞) प, yaitu bushu yang membentuk siku-siku dari bagian kiri ke bagian bawah.

(7) Kamae (構) 回四四, yaitu bushu yang tampak seolah-olah mengelilingi bagian huruf kanji lainnya.

\section{Kesalahan mahasiswa dalam menjawab soal-soal yang terdapat dalam 応用練習}

‘ouyourenshuu’ 1） soal pada bab1 hal. 25 no (1) 田中さんは今：a. 会議 b.仕事 c. 結婚 d. 世界 e. 勉強 f. 電話 中です。継続的な動作を表す。Kesalahan mahasiswa terjadi dalam memilih jawaban yang benar yaitu: 'kanji yang dikelompokkan berdasarkan kesamaan arti/makna, yaitu menyatakan kata yang bermakna 'suatu aktifitas yang dilakukan secara terus-menerus'. Jawaban yang benar yaitu (a,b,e,f); 2) soal pada bab1 hal. 25 no 
（5）今朝から：a. 心 b. 頭 c. 熱 d. 体 e. 首 f. 歯 が痛くて、困っている。体の部分を表す。 Kesalahan mahasiswa terjadi dalam mengelompokkan kanji berdasarkan anggota tubuh. Jawaban yang benar yaitu (b,d,e,f); 3) soal pada bab1 hal. 25 no (6) a.営業 b. 案内 c. 教育 $\mathrm{d}$. 運転 e. 経済 f. 歴史 を勉強するために大学へ行く。大学で勉強する科目を表す。 Kesalahan mahasiswa terjadi dalam memilih kanji yang dikelompokkan berdasarkan bidang studi yang dipelajari di kampus. Jawaban yang benar yaitu (c,e,f).

a. Kesalahan mahasiswa terjadi dalam memahami karakter dasar kanji 'bushu', yaitu bentuk bagian-bagian yang membentuk kanji huruf kanji. Contohnya (1) sanzui/さんず い kanji yang terbentuk dari karakter air atau cair yang termasuk grup $\langle$ hen $/ \wedge ん\rangle$ b. Kesalahan mahasiswa terjadi dalam menggunakan kanji yang sama dan kanji yang memiliki makna yang bersinonim 同じ漢字を使った、意味が似ている言葉 ‘Synonyms using same kanji' soal oyourenshuu pada bab 4 hal. 69 no (2) 年をとると、（）な変化に はなかなかついていけない。\{大変 急変 感激 急激 \} soal oyourenshuu pada bab 4 hal. 70 no (9) 酒や夕バコは、青少年の（）ないくせ をさまたげるといわれる。\{安全 健全 健康 安心\} 'Dikatakan bahwa alkohol dan tembakau akan menghalangi anak-anak muda' \{Keselamatan \& Kesehatan Sehat Keselamatan\}.

soal oyourenshuu pada bab 4 hal.70 no (14) あの人は若いころは（）だったが、今は弁護 士として成功した。 貧困貧乏 貧弱貧富 $\}$

c. Kesalahan mahasiswa dalam memahami dan menggunakan huruf kanji yang memiliki tanda fonem yang sama 同じ音記号を持つ漢字 pada bab 5 hal. (80)

d. Kesalahan mahasiswa dalam memahami dan menggunakan kanji yang memiliki bunyi ucap yang sama tetapi berbeda makna 同音の漢字語の意味の違い

soal oyourenshuu pada bab 5 hal 85 no (1) 国際交流の行事に参加したいが、なかなか（a.機会 b.機械）がない。 soal oyourenshuu pada bab 5 hal. 85 no (11) 今月からタクシー料金が（a.改 訂 b.改定 c. 海底) された。 soal oyourenshuu pada bab 5 hal 85 no (1)

e. Kesalahan mahasiswa dalam menjawab soal kanji yang mengecoh, yaitu huruf kanji yang digabung dengan dua kanji yang sama tetapi disusun bolak-balik sehingga mengecoh mahasiswa ketika menjawab soal-soal yang ada pada oyourenshuu.

soal oyourenshuu pada bab 5 hal 86 soal bagian II no (1) スポーツ大会の（a. 会開～b. 開会）式が行われた。 soal oyourenshuu pada bab 5 hal 86 soal bagian II no (5) 田中さんは 外国から輸入した宝石の（a. 売買 $\quad$ b. 買売）soal oyourenshuu pada bab 5 hal 86 soal bagian II no (9) 日曜日にこの町の（a. 町長 b. 長町）選挙が行われる。

f. Kesalahan mahasiswa dalam menjawab soal kanji yang mengecoh, yaitu huruf kanji yang digabung dengan dua huruf kanji yang bentuknya mirip dan digabung tanpa 
disusun bolak-balik sehingga seringkali mahasiswa terkecoh dalam menjawab soal model seperti ini. Hal ini terjadi karena mahasiswa tidak teliti, bisa juga karena mahasiswa belum benar-benar hafal huruf-huruf kanji tersebut. soal fukushuи pada bab 5 hal 75 soal no (1) 山田さんは（a. 兄弟 b. 兄第X）がいない。 soal fukushuu pada bab 5 hal 75 soal no (10) 兄は（a. 放送局 b. 放送曲X）で働いて いる。 soal fukushuu pada bab 5 hal 75 soal no (11) 先生のお宅を（a. 訪門X b. 訪問） した。soal fukushuu pada bab 5 hal 75 soal no (13) 熱があって、（a. 頭通X $\quad$ b. 頭痛）が する。

g. Kesalahan mahasiswa dalam menjawab soal, yaitu melengkapi kalimat yang mana pada bagian tertentu ada bagian kalimat yang dihilangkan dan jawaban disediakan di dalam kotak mahasiswa bisa memilih jawaban yang paling cocok untuk melengkapi bagian kalimat yang dihilangkan. Dengan memberikan jawaban yang benarb maka kalimat tersebut akan menjadi utuh lagi, baik secara teks struktur, makna, dan konteks kalimat. Dalam hal ini mahasiswa banyak melakukan kesalahan dalam menjawab, beberapa hal yang menyebabkan mahasiswa salah menjawab adalah: pertama, mahasiswa tidak mengerti maksud kalimat secara keseluruhan sehingga tidak mampu menterjemahkan dengan benar dengan demikian terjadi salah persepsi; kedua, mahasiswa tidak bisa membaca beberapa kanji yang ada dalam kalimat tersebut; ketiga, kesalahan dalam memimilih jawaban karena diantara jawaban yang tersedia di dalam kotak, ada yang kanjinya tidak bisa dibaca dan adsa pula artinya yang tidak dipahami. h. Kesalahan mahasiswa dalam membentuk atau membuat huruf kanji gabung ' jukugo' yangmana pada soal mahasiswa harus membuat kata-kata dari gabungan huruf kanji, yaitu membuat struktur gabungan huruf kanji yang dibentuk dari gabungan tiga buah huruf kanji 3 字漢語の語構成. Dalam membuat gabungan huruf kanji, ditentukan dari gabungan dua buah huruf kanji yang menjadi ini dan yang satu lagi sebagai kanji tambahan yang letaknya sebagai awalan atau akhiran 接尾辞·接頭辞てきな用法のある漢字. Pada umumnya keselahan mahasiswa terjadi dalam menentukan yangmana kanji gabungan dasar dan yangmana sebagai awalan atau akhiran. Selain itu, kesalahan mahasiswa juga terjadi dalam memahami arti atau makna baru yang dihasilakan karena adanya penggabungan antara dua huruf kanji dan satu huruf kanji tambahan, kanji tambahan sebagai awalan atau akhiran.

soal kihonrenshuu pada bab 6 hal 108 soal no (1) 最新型のカメラを買った。（最新）＋（方） =（もっとも新しい型）。soal kihonrenshuu pada bab 6 hal 108 soal no (3) 調理師になりたいと 思う。（調理） +（師）=（調理する仕事をしている）。soal kihonrenshuu pada bab 6 hal 108 soal no (8) 土地の再開発に反対する。（再） +（開発）＝（再び開発すること）

Untuk rumusan masalah yang kedua, yaitu cara untuk mengatasi kesalahankesalahan sebagaimana yang terdapat dalam rumusan masalah yang pertama adalah sebagai berikut:

(3) 1. Cara untuk mengatasi kesalahan dalam memahami dan menggunakan 漢 字の仲間 'kanji no nakama', yaitu kanji yang dikelompokkan berdasarkan 部首 
'bushu/Radicals'. Cara untuk mengatasi kesalahannya, yaitu dengan cara me-review pelajaran yang ada pada basic kanji book vol.1 dan vol.2 serta dengan cara latihan menulis berulang kali, menghafal bagian-bagian kanji, sering berlatih menggunakan huruf kanji dalam kalimat, menghafalkan arti kanji dan karakternya.

2. Cara untuk mengatasi kesalahan mahasiswa dalam menjawab soal-soal yang terdapat dalam 応用練習 'ouyourenshuu'. Cara untuk mengatasi kesalahannya, yaitu dengan memahami poin-poin pembagian kanji/youten ketika dosen menjelaskan materi inti, banyak melakukan latihan menulis dan menghafal grup kanji yang didasarkan atas, bentuk, bunyi, makna, pola penggunaan dan menghafal karakter dasar kanji. Untuk dosen pengampunya harus menjelaskan secara detail tentang empat grup kanji tersebut serta memberikan tugas kepada mahasiswa untuk me-review basic kanji book vol 1 , hal ini dilakukan agar mahasiswa bisa mengingat kemabali pola dasar pembagian kanji berdasarkan, bentuk, bunyi ucap (on-kun), makna, dan pola pemakaiannya. Kebiasaan mahasiswa menggunakan mengerjakan soal-soal atau tugas dengan alat bantu aplikasi yang ada di telepon gengam juga menyebabkan daya ingat mahasiswa terhadap pelajaran menjadi rendah. Dengan bantuan aplikasi HP mahasiswa dengan cepat dan praktis bisa menjawab soal-soal kanji dalam latihan, tetapi itu bukan cara yang baik dalam belajar karena belajar kanji dengan aplikasi yang ada di HP membuat mahasiswa menghafal kanji secara instan sehingga tidak ada proses pembelajaran. Oleh karena itu, sebaiknya dalam mengerjakan soal-soal latihan ataupun tugas sebaiknya mahasiswa menggunakan kamus.

\section{Simpulan}

Berdasarkan hasil anisis data untuk rumusan masalah yang pertama, dapat disimpulkan sebagai berikut: 1) kesalahan mahasiswa dalam memahami dan menggunakan 漢字の仲間 'kanji no nakama', yaitu kanji yang dikelompokkan berdasarkan 部首 ‘bushu/Radicals' (a) kesalahan mahasiswa dalam memahami 形のグル -フ 'katachi no guru-pu' ( pengelompokkan huruf kanji berdasarkan karakter bentuk ); (b) 音のグルーフ 'oto no guru-pu' ( pengelompokkan huruf kanji berdasarkan karakter bunyi ) atau disebut dengan 形声文字 'keisei moji' Keisei (形声 'karakter piktofonetik'); (c) 意味のグループ＇imi no guru-pu' ( pengelompokkan huruf kanji berdasarkan arti/makna ); (d) 用法のグループ 'youhou no guru-pu' (pengelompokkan huruf kanji berdasarkan penggunaannya ). 2) Kesalahan mahasiswa dalam menjawab soal-soal yang terdapat dalam 応用練習 'ouyourenshuu'. (a) Kesalahan mahasiswa terjadi dalam memilih jawaban yang benar yaitu: 'kanji yang dikelompokkan berdasarkan kesamaan arti/makna, yaitu menyatakan kata yang bermakna 'suatu aktifitas yang dilakukan secara terus-menerus'; (b) Kesalahan mahasiswa terjadi dalam mengelompokkan kanji berdasarkan anggota tubuh; (c) Kesalahan mahasiswa terjadi dalam memilih kanji yang dikelompokkan berdasarkan bidang studi yang dipelajari di kampus. 3) Kesalahan mahasiswa terjadi dalam memahami karakter dasar kanji 'bushu', yaitu bentuk bagian-bagian yang membentuk kanji huruf kanji. 4) Kesalahan mahasiswa terjadi dalam menggunakan kanji yang 
sama dan kanji yang memiliki makna yang bersinonim. 5) Kesalahan mahasiswa dalam memahami dan menggunakan huruf kanji yang memiliki tanda fonem yang sama. 6) Kesalahan mahasiswa dalam memahami dan menggunakan kanji yang memiliki bunyi ucap yang sama tetapi berbeda makna. 7) Kesalahan mahasiswa dalam menjawab soal kanji yang mengecoh, yaitu huruf kanji yang digabung dengan dua kanji yang sama tetapi disusun bolak-balik sehingga mengecoh mahasiswa ketika menjawab soal-soal yang ada pada oyourenshиu. 8) Kesalahan mahasiswa dalam menjawab soal kanji yang mengecoh, yaitu huruf kanji yang digabung dengan dua huruf kanji yang bentuknya mirip dan digabung tanpa disusun bolak-balik sehingga seringkali mahasiswa terkecoh dalam menjawab soal model seperti ini. Hal ini terjadi karena mahasiswa tidak teliti, bisa juga karena mahasiswa belum benar-benar hafal huruf-huruf kanji tersebut. 9) Kesalahan mahasiswa dalam menjawab soal, yaitu melengkapi kalimat yangmana pada bagian tertentu ada bagian kalimat yang dihilangkan dan jawaban disediakan di dalam kotak mahasiswa bisa memilih jawaban yang paling cocok untuk melengkapi bagian kalimat yang dihilangkan. 10) Kesalahan mahasiswa dalam membentuk atau membuat huruf kanji gabung 'jukugo' pada soal mahasiswa yang harus membuat kata-kata dari gabungan huruf kanji.

Untuk rumusan masalah yang kedua dapat disimpulkan bahawa, pertama cara untuk mengatasi kesalahannya, yaitu dengan cara me-review pelajaran yang ada pada basic kanji book vol.1 dan vol.2 serta dengan cara latihan menulis berulang kali, menghafal bagian-bagian kanji, sering berlatih menggunakan huruf kanji dalam kalimat, menghafalkan arti kanji dan karakternya; kedua cara untuk mengatasi kesalahannya, yaitu dengan memahami point-point pembagian kanji/ youten ketika dosen menjelaskan materi inti, banyak melakukan latihan menulis dan menghafal grup kanji yang didasarkan atas, bentuk, bunyi, makna, pola penggunaan dan menghafal karakter dasar kanji. Untuk dosen pengampunya harus menjelaskan secara detail tentang empat grup kanji tersebut serta memberikan tugas kepada mahasiswa untuk me-review basic kanji book vol 1, hal ini dilakukan agar mahasiswa bisa mengingat kemabali pola dasar pembagian kanji berdasarkan, bentuk, bunyi ucap (on-kun), makna, dan pola pemakaiannya; ketiga kebiasaan mahasiswa menggunakan mengerjakan soal-soal atau tugas dengan alat bantu aplikasi yang ada di telepon gengam juga menyebabkan daya ingat mahasiswa terhadap pelajaran menjadi rendah. Dengan bantuan aplikasi HP mahasiswa dengan cepat dan praktis bisa menjawab soalsoal kanji dalam latihan, tetapi itu bukan cara yang baik dalam belajar karena belajar kanji dengan aplikasi yang ada di HP membuat mahasiswa menghafal kanji secara instan sehingga tidak ada proses pembelajaran. Oleh karena itu, sebaiknya dalam mengerjakan soal-soal latihan ataupun tugas sebaiknya mahasiswa menggunakan kamus.

\section{Daftar Pustaka}

Chaer, Abdul. 1994. Linguistik Umum. Jakarta: PT. Rineka Cipta. 
Chusna, Fadhilal. 2014. Analisis Kesalahan Mahasiswa dalam Menulis dan Membaca Kanji: Fakultas Sastra UNIKOM.

Mahsun, 2005. Metode Penelitian Bahasa: Tahapan Strategi, Metode, dan Tekniknya. Jakarta: PT Raja Grafindo Perkasa

Setyawati, Nanik. 2010. Analisis Kesalahan Berbahasa Indonesia. Surakarta: Yuma Pustaka.

Sudjianto dan Dahidi, A. 2004. Pengantar Linguistik Bahasa Jepang. Jakarta: Kesaint Blanc.

Verhaar, J.W.M. 2001. Asas-Asas Linguistik Umum. Cetakan ketiga. Yogyakarta: Gajahmada University Press. 